\title{
HYDROXYAPATITE FOR REMOVAL OF HEAVY METALS FROM WASTEWATER
}

\author{
ALEXANDRA AVRAM ${ }^{\mathrm{a}}$, TIBERIU FRENTIU ${ }^{\mathrm{a}}$, OSSI HOROVITZ ${ }^{\mathrm{a}, *}$, \\ AURORA MOCANU ${ }^{a}$, FIRUTA GOGA ${ }^{a}$, MARIA TOMOAIA-COTISEL ${ }^{a, b}$
}

\begin{abstract}
HAP powder of a low crystallinity and rather large specific surface area was synthesized by an environmentally friendly, cost effective precipitation method, and characterized by XRD, FTIR, and BET isotherms. TEM and AFM are used to envisage the surface of HAP nano particles, showing a high porosity of this ceramic powder. It was used for the removal of metals (Al, Cd, Co, Cr, Cu, Fe, Mn, Ni, $\mathrm{Pb}$, and $\mathrm{Zn}$ ) from mine wastewater. Metal contents in the initial and treated samples were quantified by inductively coupled plasma atomic emission spectrometry and high-resolution continuum source atomic absorption spectrometry. By the use of HAP, an efficient removal of all metals was ensured. The increase of $\mathrm{Ca}^{2+}$ ions content in the treated water suggests an ion exchange mechanism.
\end{abstract}

Keywords: hydroxyapatite, heavy metal removal, mine wastewater, sorption kinetics

\section{INTRODUCTION}

The presence of heavy metals in wastewater [1-6], resulting from mining operations, various manufacturing industries, leather tanning, paper production, fertilizers, photographic materials, explosives, is a major environmental concern. These elements can enter the human body both in a direct manner and following the food chain [7,8]. Easily accumulated by organisms and nonbiodegradable [1] heavy metals can lead to a large number of potentially deadly health issues [8-10] Some metals can be toxic even in small concentrations [11]. The admissible levels of heavy metals are regulated in most countries [12, 13], during the wastewater treatment.

\footnotetext{
a Babeş-Bolyai University, Faculty of Chemistry and Chemical Engineering, 11 Arany Janos str., RO-400028, Cluj-Napoca, Romania

${ }^{\mathrm{b}}$ Academy of Romanian Scientists, Splaiul Independenţei 54, 050094 Bucharest, Romania

*Corresponding author: ossihor@yahoo.com
} 
With water playing a crucial role in a sustainable development, the removal of heavy metals from contaminated waters has been the subject of many studies. Some examples are: strontium [14], iron [2, 15-18], lead [1-4, 6, 15, 18-28], cadmium [2, 3, 7, 18, 25, 29-33], zinc [2, 5, 15, 16,18, 22, 23, 29, 32], nickel [2, 8, 10, 17, 18, 31], chromium [18, 32, 35], arsenic [9], copper [17$20,22,24,25,32,33]$, manganese [15, 16, 23], mercury [36], cobalt [18, 37]).

Some of the methods employed in the removal of these elements involve physical (e.g., membrane filtration, coagulation, adsorption on both stable and floating beds, reverse osmosis), chemical (such as, neutralization with various materials, including lime, ion exchange, adsorption, chemical oxidation or reduction) and biological processes [2-4, 9, 14, 15, 23, 34, 35]. The latter category presents certain models that are not easily implemented in industrial conditions as they require high manufacturing costs and are too complex [2].

The published data revealed that adsorption onto solids has been a preferred method, due to being simple, highly-selective, relatively low cost and showing very few to no problems [11, 14]. Among organic and inorganic materials used are: both natural $[7,10,32,35]$ and synthetic hydroxyapatite (HAP) [1, 2, 19, 21, 24], and various composites containing it [3, 4, 6, 25, 37], zeolites [23] polymers, organic resins [8], silicate sand, bentonite [6, 23], carbon nanotubes [4], coals [8,9], bone charcoals [17], and natural waste materials (spent coffee grounds, fruit waste, nut and eggshells, rice husks, bamboo, saw dust, tea waste, grape stalks, algae, wood) $[1,9,26,32,34$, 37].

Hydroxyapatite (HAP, $\left.\mathrm{Ca}_{10}\left(\mathrm{PO}_{4}\right)_{6}(\mathrm{OH})_{2}\right)$, a naturally available form of calcium phosphate and a component of hard tissues [15, 26, 27]), has been reported to act as an efficient ion removal material for various heavy metals from aqueous solutions due to its excellent reactivity and low water solubility $[8,14,35]$. The high structure stability of HAP, along with its flexibility permit a large variety of substitutions (especially $\mathrm{Ca}$ with divalent heavy metal ions, such as $\mathrm{Pb}, \mathrm{Cu}, \mathrm{Sb}, \mathrm{Zn}, \mathrm{Cd}, \mathrm{Co}, \mathrm{Ni}, \mathrm{U}, \mathrm{Hg}, \mathrm{As}[6,8,18,27,28,33,34,38-$ 40], of great importance in the field of environmental science [34].

HAP can be synthesized through various methods, including sol-gel [24], wet precipitation [6, 31, 41-44], combustion and ultrasonic [32]. Its slightlyalkaline $\mathrm{pH}$ and high biocompatibility will not likely cause any form of secondary environmental damage [19]. The efficiency of HAP in removing heavy metal ions heavily depends on ion nature, charge, diameter and concentration, as well as the properties of the treated water $(\mathrm{pH}$, temperature) $[8,25]$. In addition, the removal of HAP from the purified aqueous solution is not without problems [38], as is the isolation of some important heavy metals from it $[3,36]$. 
Some studies have tried to enhance the properties of hydroxyapatite (improved porosity, specific surface area, mechanical properties, etc. [6, 27]) through the addition of non-toxic polymers, abundantly found in nature dextran [27], chitosan [4, 38], carboxymethyl cellulose [26, 36], alginate, gelatin [21]. However, these additions do tend to increase the manufacturing cost, thus making it difficult to translate from a laboratory level to an industrial one. Other studies have tried to combine the reactivity of hydroxyapatite as an adsorbent with a magnetic separation process for an increased adsorption of heavy metal ions, synthesizing magnetic HAP particles [22] or magnetic core-shell nanocomposites [5]. Ca deficient HAP has also been reported to exhibit different ion substitution ability to stoichiometric HAP [18], due to its large number of $\mathrm{Ca}$-deficient sites. While the main focus of some research groups is to enhance the properties of HAP by using its composites with various polymers, such as chitosan, others choose to focus on cost effectiveness, by synthesizing hydroxyapatite, using environmental friendly methods.

The aim of this study was to develop a rapid and low cost method to remove metal ions from mine wastewaters, using a low crystalline HAP prepared by a precipitation method [41]. This study meant to correlate the ion adsorption behaviour of a low crystallinity HAP, and its efficiency in removal of a large range of various metals ( $\mathrm{Al}, \mathrm{Cd}, \mathrm{Co}, \mathrm{Cr}, \mathrm{Cu}, \mathrm{Fe}, \mathrm{Mn}, \mathrm{Ni}, \mathrm{Pb}$, and $\mathrm{Zn}$ ) from a multi-component Roșia Montana mine wastewater.

\section{RESULTS AND DISCUSSION}

\section{Hydroxyapatite characterization}

$X$-ray diffraction pattern (Fig. 1) shows, by comparison with PDF 740566 (characteristic for stoichiometric HAP) that synthesized HAP sample contains only pure hydroxyapatite. Average crystallite size was evaluated, using Scherrer formula, to be $23.3 \mathrm{~nm}$, and the degree of crystallinity was obtained, using Reflex computer program, as $32.3 \%$. This nanoHAP with rather low crystallinity is expected to present good adsorptive properties.

The FTIR spectrum (Fig. 2) presents the absorption bands of hydroxyapatite, corresponding to vibrations of $\mathrm{PO}_{4}$ and $\mathrm{OH}$ groups characteristic for $\mathrm{HAP}$, and of $\mathrm{OH}$ groups from adsorbed water

An example of TEM image (Fig.3) for the HAP sample in aqueous dispersion reveals acicular assemblies of particles, with a diameter of $15-20 \mathrm{~nm}$. These dimensions are confirmed by the atomic force microscopy (AFM) images (an example is given in Fig. 4).

Brunauer-Emmett-Teller (BET) analysis on HAP powder gave a specific surface area of $106.5 \mathrm{~m}^{2} / \mathrm{g}$ and a specific volume of the pores of $0.358 \mathrm{~cm}^{3} / \mathrm{g}$. 
The large specific surface area recommends HAP as a good adsorbent. From the surface area, a rough estimation of the particles size is possible, using the formula

$$
d=\frac{6}{s \rho}
$$

where $d$ is the average diameter of particles, $S$ is the specific surface area and $\rho$ is the density of the material; using the theoretical density of HAP: $3.14 \mathrm{~g} / \mathrm{cm}^{3}$ [45], a value of $17.9 \mathrm{~nm}$ is found for the average diameter of a HAP particle.

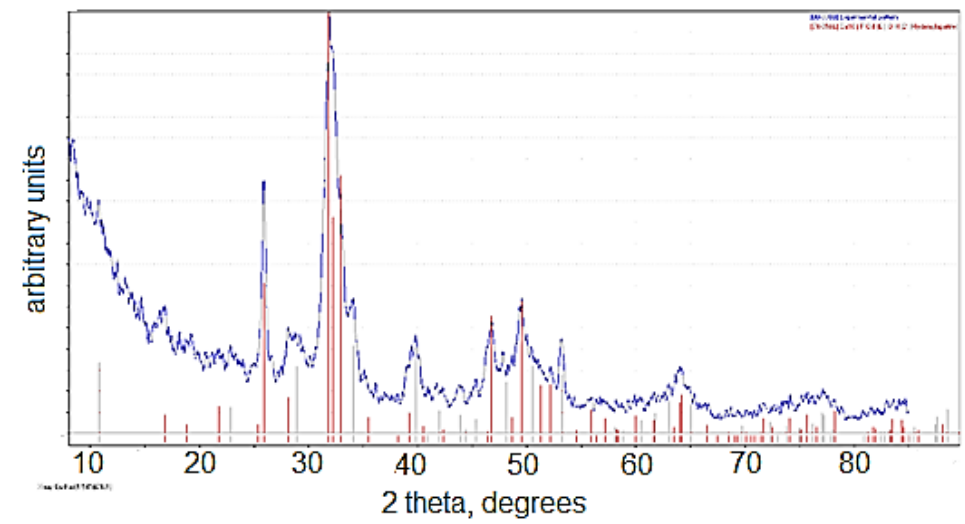

Figure 1. XRD pattern for HAP sample, compared with PDF 74-0566 for stoichiometric hydroxyapatite

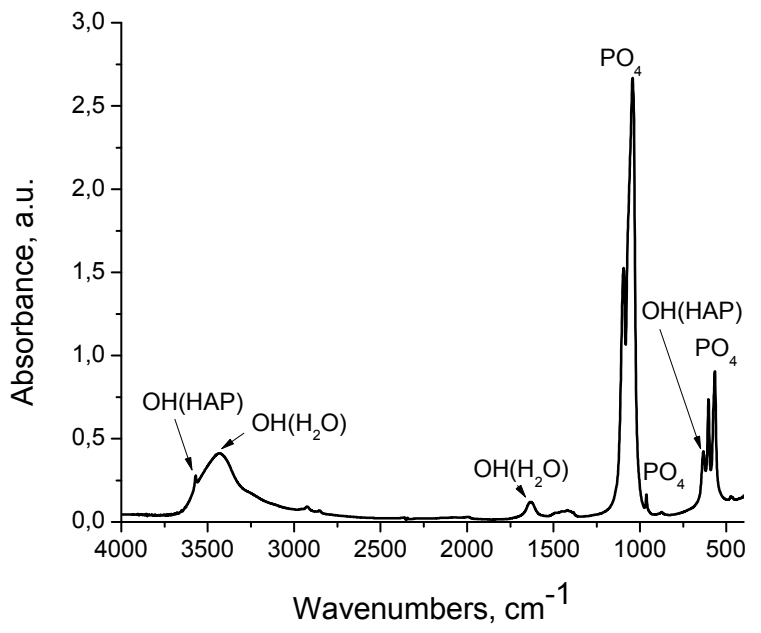

Figure 2. FTIR spectrum of HAP 


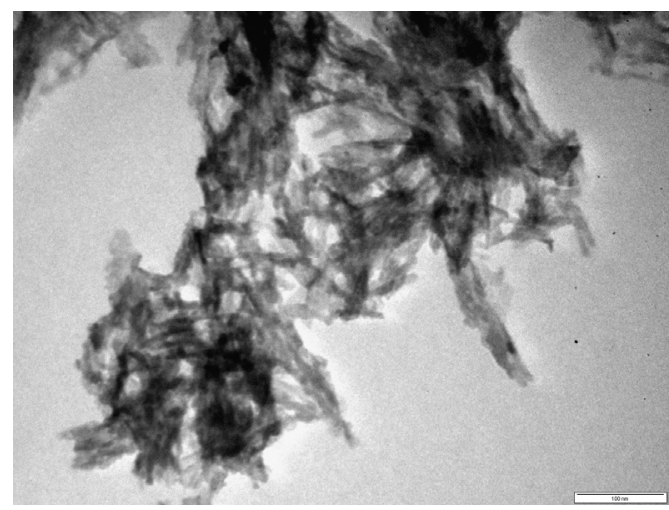

Figure 3. TEM image of HAP; the bar is $100 \mathrm{~nm}$

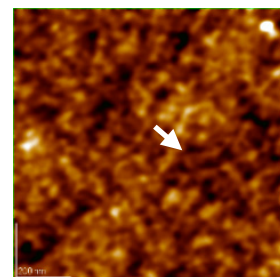

a

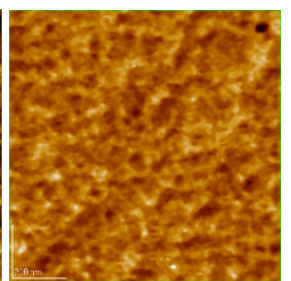

b

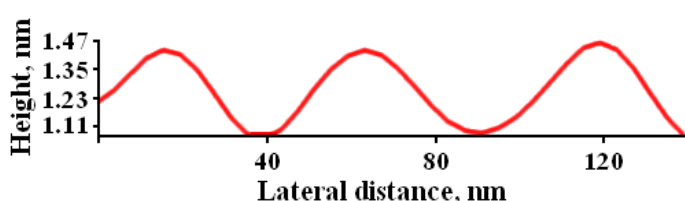

C

Figure 4. AFM images for HAP, adsorbed on glass support: 2D topography (a), phase image (b), cross section profile (c) along the arrow in panel (a); scanned area of $1 \mu \mathrm{m} \times 1 \mu \mathrm{m}$

\section{Metal ions removal from mine wastewater samples}

The removal degree, $\mathrm{R}(\%)$, was calculated as

$$
R(\%)=100 \frac{c_{0}-c_{e}}{c_{0}}
$$

where $\mathrm{c}_{0}$ is the element' content $(\mathrm{mg} / \mathrm{L})$ in the initial mine wastewater sample, while $\mathrm{C}_{\mathrm{e}}$ is its final content at equilibrium, after adsorption for 120 min on HAP. The initial and final content, and the calculated removal degree for each metal are given in Table 1, along with the standard errors from determinations on 3 parallel samples. In the same table the limit values for the metal content admissible in wastewater discharged in natural waters [12] are indicated.

All metal ions are removed to final values below the values admitted in standards for wastewaters. The removal degree is near to $100 \%$ for metals existent in higher amounts in the wastewater, and lower (60-80\%) for those present initially only in very low concentration (even under the admitted limit value - Table 1). Probably, their sorption on the surface of HAP nanoparticles 
is limited by the simultaneous sorption of ions existent in high excess in the wastewater. The confidence intervals are wide due to the existence of some metals $(\mathrm{Cu}, \mathrm{Cr}, \mathrm{Pb}, \mathrm{Ni})$ near the quantification limit of analytical methods. However, an efficient removal of these metals below the values of admitted levels in wastewater in the presence of those in high concentrations can also be observed.

Table 1. Metal removal from mine wastewaters using nano HAP powder (results are given as mean \pm confidence interval for $n=3$ and $95 \%$ confidence level)

\begin{tabular}{|c|c|c|c|c|}
\hline Metal & $\begin{array}{c}\text { Initial content } \\
\mathrm{C}, \mathrm{mg} / \mathrm{L}\end{array}$ & $\begin{array}{c}\text { Final content } \\
\mathrm{Ce}, \mathrm{mg} / \mathrm{L}\end{array}$ & $\begin{array}{c}\text { Removal } \\
\text { degree, \% }\end{array}$ & $\begin{array}{c}\text { Limit value for } \\
\text { wastewater, } \mathrm{mg} / \mathrm{L} \\
{[12]}\end{array}$ \\
\hline $\mathrm{Al}$ & $313 \pm 37$ & $1.9 \pm 0.6$ & $99 \pm 12$ & 5 \\
$\mathrm{Cd}$ & $0.21 \pm 0.07$ & $0.068 \pm 0.043$ & $68 \pm 58$ & 0.2 \\
$\mathrm{Co}$ & $1.1 \pm 0.6$ & $0.15 \pm 0.07$ & $86 \pm 63$ & 1 \\
$\mathrm{Cr}$ & $0.046 \pm 0.024$ & $0.009 \pm 0.006$ & $80 \pm 66$ & 1 \\
$\mathrm{Cu}$ & $1.0 \pm 0.7$ & $0.014 \pm 0.011$ & $99 \pm 71$ & 0.1 \\
$\mathrm{Fe}$ & $92 \pm 9$ & $0.9 \pm 0.6$ & $99 \pm 10$ & 5 \\
$\mathrm{Mn}$ & $190 \pm 5$ & $0.81 \pm 0.48$ & $100 \pm 3$ & 1 \\
$\mathrm{Ni}$ & $0.47 \pm 0.22$ & $0.16 \pm 0.09$ & $66 \pm 77$ & 0.5 \\
$\mathrm{~Pb}$ & $0.16 \pm 0.07$ & $0.066 \pm 0.045$ & $59 \pm 88$ & 0.2 \\
$\mathrm{Zn}$ & $14.4 \pm 0.9$ & $0.18 \pm 0.08$ & $99 \pm 6$ & 0.5 \\
\hline
\end{tabular}

a the removal degree and its confidence interval were calculated by a concentration difference and pooled standard deviation

\section{Adsorption kinetics of $\mathbf{M n}^{2+}$ ions on HAP}

The concentration of $\mathrm{Mn}^{2+}$ ions in mine wastewater was measured at different time points. The $\mathrm{Mn}$ uptake, $\mathrm{x}$, from the contaminated solution on the HAP, was calculated in $\mathrm{mg} \mathrm{Mn} / \mathrm{g}$ HAP for each moment by the formula:

$$
x=\frac{\left(c_{0}-c_{t}\right) V}{m}
$$

where $\mathrm{c}_{\mathrm{o}}$ is the initial $\mathrm{Mn}^{2+}$ content, $\mathrm{c}_{t}$ is the content at time $t(\mathrm{mg} / \mathrm{L}), \mathrm{V}$ is the volume of solution $(0.1 \mathrm{~L})$, and $m$ is the mass of HAP $(10 \mathrm{~g})$.

In order to assess the kinetics of Mn removal from the solution, three kinetic models were used [3], assuming a pseudo-first-order kinetic [46], a pseudo-second order kinetic [47], and an intraparticle diffusion model [48]. equation:

The first order kinetic (Lagergren kinetic) would be described by the

$$
\frac{d x}{d t}=k_{1}\left(x_{e}-x\right)
$$

where $x_{e}$ is the sorbed amount at equilibrium, assumed to be the value at $960 \mathrm{~min}$, and $\mathrm{k}_{1}$ is the first order adsorption rate constant. The representation of the linearized form of the integrated equation:

$$
\ln \left(x_{e}-x\right)=\ln x_{e}-k_{1} t
$$


as $\ln \left(x_{e}-x\right)=f(t)$ should give a straight line if the equation would apply. The poor linearity observed in Fig. $5 a\left(r^{2}=0.62\right)$ shows this model to be inadequate here.

The $2^{\text {nd }}$ order kinetic equation:

$$
\frac{d x}{d t}=k_{2}\left(x_{e}-x\right)^{2}
$$

with $\mathrm{k}_{2}$ as second order sorption rate constant, linearized after integration as:

$$
\frac{t}{x}=\frac{1}{k_{2} x_{e}^{2}}+\frac{t}{x_{e}}
$$

gives in the representation: $t / x=f(t)$ a perfect straight line (Fig. $5 b)$, with $r^{2}=$ 0.9999; thus this model best describes the kinetics of Mn sorption on HAP.

The third model assumes the diffusion to be the rate-limiting step in the sorption, using an equation for intraparticles diffusion rate:

$$
x=k_{d} t^{1 / 2}+\text { const. }
$$

where $k_{d}$ is the diffusion rate constant and const. an integration constant. The representation of $x=f\left(t^{1 / 2}\right)$ in Fig. $5 c$ shows no linear correlation $\left(r^{2}=0.32\right)$, so this model is not applicable in our case. Nevertheless, for the first 15 minutes of sample contact with HAP, a quite good correlation is found $\left(r^{2}=0.985\right.$, Fig. $\left.5 d\right)$ with $\mathrm{k}_{\mathrm{d}}=0.480 \pm 0.034$ and const. $=0.02 \pm 0.07$.

From the parameters of the linear plot of equation (5a) for the pseudo second order kinetics: intercept, $a=0.57502$, and slope, $b=0.52808$, we can calculate the $x_{e}$ value: $x_{e}=1 / b=1.894 \mathrm{mg} / \mathrm{g}$, very close to the assumed value 1.891 , and the pseudo second order rate constant $k_{2}=1 /\left(a x_{e}^{2}\right)=0.485$ $\mathrm{g} \cdot \mathrm{mg}^{-1} \cdot \mathrm{min}^{-1}=29.1 \mathrm{~g} \cdot \mathrm{mg}^{-1} \cdot \mathrm{h}^{-1}$. A second order reaction kinetic was observed also for the sorption on hydroxyapatite of other metal ions, such as $\mathrm{Cd}^{2+}$ [3], $\mathrm{Cu}^{2+}$ [19], $\mathrm{Ni}^{2+}$ [10], $\mathrm{Zn}^{2+}$ [34], $\mathrm{Cr}(\mathrm{VI})$ [35], or $\mathrm{Pb}^{2+}$ [3, 19, 21]. For the adsorption of $\mathrm{Co}^{2+}$ on a HAP/zeolite composite [34], $\mathrm{Pb}^{2+}$ on a HAP/bentonite composite [6], $\mathrm{Cr}(\mathrm{VI}), \mathrm{Zn}^{2+}$, and $\mathrm{Cd}^{2+}$ on HAP/chitosan composite [38], of $\mathrm{Mn}^{2+}, \mathrm{Fe}^{2+}, \mathrm{Ni}^{2+}$, and $\mathrm{Cu}^{2+}$ on charcoal [17], the same pseudo-second order kinetic was found.

We could assume that for the initial stage (about $15 \mathrm{~min}$ ), diffusion is important; subsequently, the second order chemical process is rate determining.

Hydroxyapatite immobilizes heavy metal ions from aqueous solutions in various ways. Some of these mechanisms include: surface complexation, ion exchange, dissolution followed by the precipitation of metal phosphates, and the substitution of $\mathrm{Ca}^{2+}$ present in the HAP structure by other divalent heavy metals during co-precipitation [16, 18, 28, 34]. Literature presents very little information on the specific contribution of these processes, leading researchers to believe that they are all employed at the same time $[16,34]$ (in aqueous solutions containing multiple competing heavy metal ions [33]). 


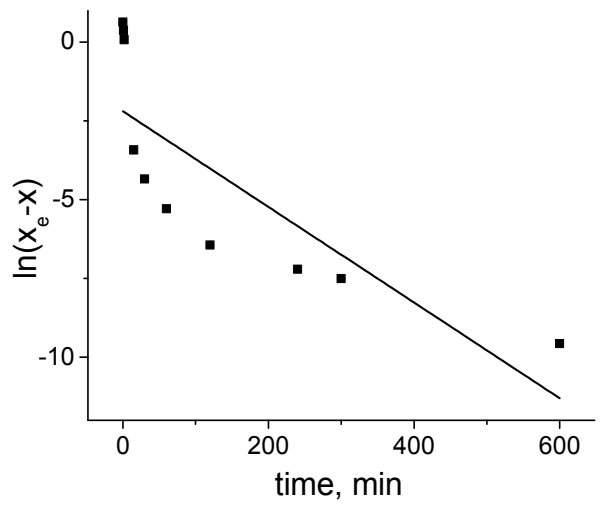

a

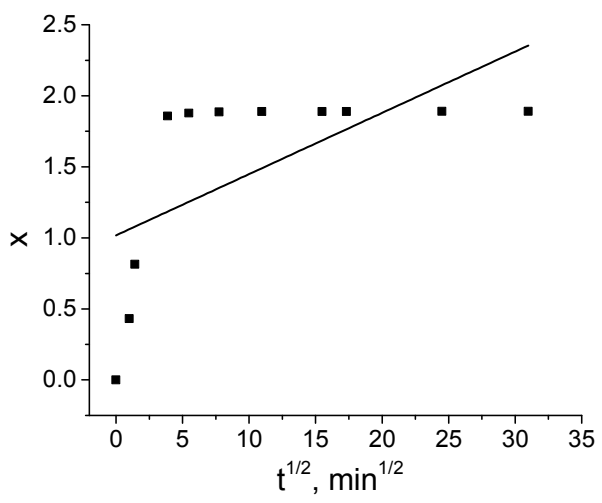

C

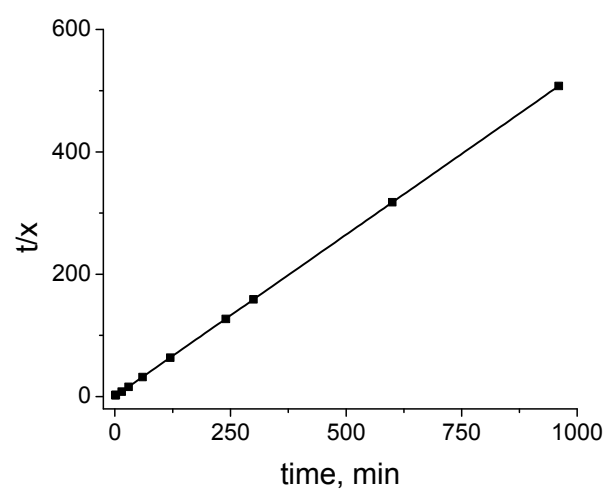

b

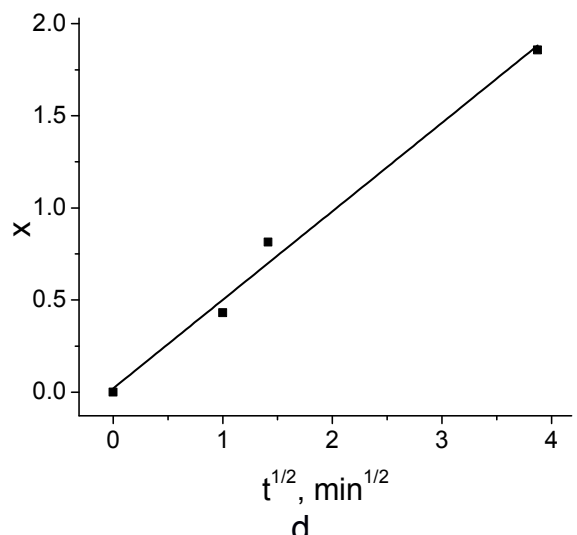

Figure 5. Plots of linearized kinetic equations for pseudo first order (a), pseudo second order (b) and intramolecular diffusion (c, d) kinetics of Mn sorption on HAP

The sorption process of metal ions involves complex adsorption on the adsorption sites on the HAP surface [19]. For the mechanism of ions retention, ion exchange was considered, for instance for $\mathrm{Pb}^{2+}[1,15]$, where the incorporation of $\mathrm{Pb}$ in the HAP lattice was evidenced, or for $\mathrm{Cd}^{2+}$ [33]. For $\mathrm{Zn}^{2+}$, $\mathrm{Fe}^{2+}$ and $\mathrm{Mn}^{2+}$ the formation of metal phosphates was considered [15], by dissolution of HAP and precipitation of phosphate ions with the heavy metal ions.

During the metals removal process, an increase of the $\mathrm{Ca}^{2+}$ content in the solution was observed, from initially $115.5 \mathrm{mg} / \mathrm{L}$ to $287.3 \mathrm{mg} / \mathrm{L}$ (after $120 \mathrm{~min}$ ), which corresponds to the release of $4.29 \mathrm{mmol} / \mathrm{L}$. The total amount of heavy metal ions removed from the solution (Table 1) in the same time is $5.35 \mathrm{mmol} / \mathrm{L}$. So, most of the heavy metal ions were exchanged with $\mathrm{Ca}^{2+}$ ions during sorption, while other were simply adsorbed on the surface of HAP. 


\section{CONCLUSIONS}

Our study has evidenced that low crystallinity HAP can be successfully used in heavy metal removal from mine wastewater. For all the 10 metals analyzed ( $\mathrm{Al}, \mathrm{Cd}, \mathrm{Co}, \mathrm{Cr}, \mathrm{Cu}, \mathrm{Fe}, \mathrm{Mn}, \mathrm{Ni}, \mathrm{Pb}$, and $\mathrm{Zn}$ ), their content was rapidly reduced by contact with HAP under the legal admissible limits for wastewater discharge in natural environment. The importance of ion exchange in sorption processes was revealed and the pseudo- $2^{\text {nd }}$ order kinetics of manganese ions sorption on HAP was assessed.

\section{EXPERIMENTAL SECTION}

The nano-hydroxyapatite was prepared by the direct reaction of calcium nitrate and diammonium hydrogen phosphate at basic $\mathrm{pH}$. The calcium nitrate solution $\left(0.25 \mathrm{M}\right.$ ), prepared from $\mathrm{Ca}\left(\mathrm{NO}_{3}\right)_{2} \cdot 4 \mathrm{H}_{2} \mathrm{O}$ (pure p.a., Merck) in ultrapure water, with addition of $25 \%$ ammonia solution to $\mathrm{pH} 8.5$ was mixed at room temperature with an equal volume of $0.15 \mathrm{M}\left(\mathrm{NH}_{4}\right)_{2} \mathrm{HPO}_{4}$ (pure p.a., SigmaAldrich), with $\mathrm{pH} 11$ (fixed with ammonia solution). The mixing was achieved rapidly, using a peristaltic pump (Masterflex LS Digital Drive, 600 RPM, 115/230 VAC, EW-07523-80) and an impact reactor type $Y$ To assist the formation of the HAP lattice, the so obtained dispersion was maintained for a maturation stage at room temperature $\left(22^{\circ} \mathrm{C}\right)$ for $24 \mathrm{~h}$. After subsequent filtration and washing with ultrapure water (until no nitrate ions were detected), the wet precipitate was dried by lyophilization (freeze drying process). The dried material was dispersed by grinding in an agate mortar.

X-Ray Diffraction (XRD) investigations: a DRON-3 diffractometer was used, in Bragg-Brentano geometry, equipped with a X-ray tube with Co $\mathrm{K}_{\alpha}$ radiation (wavelength $1.79026 \AA$ ), $25 \mathrm{kV} / 20 \mathrm{~mA}$. FTIR spectra were determined on the HP powder in $\mathrm{KBr}$ pellets, using a FTIR spectrometer JASCO 6100 in the $4000-400 \mathrm{~cm}^{-1}$ range of wave numbers, with a $4 \mathrm{~cm}^{-1}$ resolution.

TEM images were obtained with a transmission electron microscope (TEM, JEOL - JEM 1010); the aqueous dispersion of the HAP sample was adsorbed on the specimen grids. The same HAP dispersion was used for the preparation of samples for atomic force microscopy, AFM JEOL 4210 used in tapping mode, [49-53], after HAP adsorption for $10 \mathrm{~s}$ on glass. The images were processed by the standard AFM-JEOL procedures.

For BET analysis an automated Sorptomatic 1990 instrument was used, with nitrogen adsorption at $77 \mathrm{~K}$. The calculation of surface area was made in the $P / P_{0}$ range between 0.03 and 0.3 , and the total pore volume was determined at $P / P_{0}=0.95$. Before the analysis the samples were outgassed for $6 \mathrm{~h}$ at $70^{\circ} \mathrm{C}$. 
The ion adsorption capacity of synthetic hydroxyapatite was studied using raw, non-treated wastewater collected from Roşia Montană, Alba County, Romania. Adsorption experiments were carried out in controlled conditions using a predetermined wastewater/HAP ratio, namely $100 \mathrm{ml}$ wastewater to $10 \mathrm{~g}$ HAP. All experiments were performed by submitting the HAP/wastewater mixture to magnetic stirring for ' 100 minutes, followed by a 20 minutes sedimentation period. For manganese, samples were collected in a time span ranging from one minute to 960 minutes, for kinetics determination purposes. All samples were filtered using Millipore syringe filters $(0.22 \mu \mathrm{m})$.

Treated water samples were analyzed by Inductively Coupled Plasma Atomic Emission Spectrometry using a Spectro Ciros CCD spectrometer (Spectro Ciros, Germany) and High-Resolution Continuum Source Atomic Absorption Spectrometry using a ContrAA 300 flame spectrometer (Analytik Jena, Germany). The results are calculated as the mean values of 3 independent measurements.

\section{ACKNOWLEDGMENTS}

This work was supported by the Romanian Executive Agency for Higher Education, Research, Development and Innovation Funding (UEFISCDI) through grant 241/2014 and 83/2017.

\section{REFERENCES}

1. V.N. Narwade, M.P. Mahabole, K.A., Bogle, R.S. Khaimar, International Journal of Engineering Science and Innovative Technology, 2014, 3, 324.

2. N. Moayyeri, K. Saeb, E. Biazar, International Journal of Material Science and Engineering, 2013, 3, 13.

3. S. Park, A. Gomez-Flores, Y.S. Chung, H. Kim, Journal of Chemistry, 2015, Article ID 396290, 12 pp.

4. Y. Lei, J.-J. Guan, W. Chen, Q.-F. Ke, C.-Q. Zhang, Y.-P. Guo, RCS Advances, 2015, 5, 25462.

5. F. Foroughi, S.A. Hassanzadeh-Tabrizi, J. Amighian, A. Saffar-Teluri, Ceramics International, 2015, 41, 6844 .

6. T.M. Hieu Do, P.T.T. Tran, A.K. Ton, M.V. Le, Journal of Environmental Science and Technology B, 2016, 5, 371 .

7. O.K. Ince, M. Ince, N.M. Karaaslan, V. Yonten, Analytical. Letters, 2016, 49, 2513.

8. S. Sharma, S. Garg, Research Cell: An International Journal of Engineering Sciences, 2014, 3, 201.

9. M. Mirhosseini, E. Biazar, K. Saeb, Current World Environment, 2014, 9, 331. 
10. S. Zamani, E. Salahi, I. Mobasherpour, Canadian Chemical Transactions, 2013, $1,173$.

11. L.V. Constantin, S. Iconaru, C.S. Ciobanu, Romanian Reports in Physics, 2012, 64, 788.

12. ${ }^{* * *}$ HOTĂRÂRE nr. 352 din 21 aprilie 2005 privind modificarea si completarea Hotărârii Guvernului nr. 188/2002 pentru aprobarea unor norme privind condițiile de descărcare in mediul acvatic a apelor uzate, Monitorul Oficial Nr 398, 11 mai 2005, Art. I, 35.

13. Guidelines for drinking-water quality: fourth edition incorporating the first addendum, Geneva, World Health Organization, 2017, Licence: CC BY-NCSA 3.0 IGO.

14. Y. Nishiyama, T. Hanafusa, J. Yamashita, Y. Yamamoto, T. Ono, Journal of Analytical and Nuclear Chemistry, 2016, 64, 1279.

15. J. Oliva, J. De Pablo, J.-L. Cortina, J. Cama, C. Ayora, Journal of Hazardous Materials, 2010, 184, 364.

16. S. Varvara, M. Popa, R. Bostan, A. Lancranjan, M. Moldovan, C. Rosu, Studia UBB Ambientum, 2015, 60, 145.

17. J.C. Moreno, R. Gomez, L. Giraldo, Materials, 2010, 3, 452.

18. T. Miriguchi, S. Nakagawa, F. Kaji, Phosphorus Research Bulletin, 2008, $22,54$.

19. Y. Song, J. Gao, Y. Zhang, S. Song, Nanomaterials and Nanotechnology, 2016, 6, 1.

20. J.R. Parga, J.L. Valenzuela, V. Vazquez, M. Rodriguez, H. Moreno, Materials Sciences and Applications, 2013, 4, 231.

21. K. Sangeetha, G. Vasugi, E.J. Girija, Journal of Chemtech Research, 2015, 8, 117.

22. C. Stotzel, F.A, Muller, F. Reinert, F. Niederdraenk, J.E. Barralet, U. Gbureck, Colloids and Surfaces B: Biointerfaces, 2009, 74, 91.

23. S. M. Abdallah, Journal of Novel Applied Sciences, 2014, 3, 5

24. A. Deptula, J. Chwastowska, W. Lada, T. Olczak, D. Wawszczak, E. Sterlinska, B. Sartowska, M. Brykala, K.C. Goretta, Advances in Science and Technology, 2006, 45, 2198.

25. M. Vila, S. Sanchez-Salcedo, M. Cicuendez, I. Izquierdo-Barba, M. Vallet-Regi, Journal of Hazardous Materials, 2011, 192, 71.

26. D.C. Manatunga, R.M. De Silva, K.M.N. De Silva, R. Ratnaweera, RSC Advances, 2016, 6, 105618.

27. A. Costescu, E. Andronescu, B.S. Vasile, R. Trusca, P. Le Coustumer, E.S. Barna, S.L. Iconaru, M. Motelica-Heino, C.S. Ciobanu, U.P.B. Scientific Bulletin, Series B, 2014, 76, 71.

28. Q.Y. Ma, S.J. Traina, T.J. Logan, Environmental Science and Technology, 1993, 27, 1803.

29. Y. Feng, J.-L. Gong, G.-M. Zeng, Q.-Y. Niu, H.-Y. Zhang, C.-G. Niu, J.-H. Deng, M. Yan, Chemical Engineering Journal, 2010, 162, 487.

30. K.A. Matis, A.I. Zoubulis, S. Mandjiny, D. Zamboulis, Separation Science and Technology, 1997, 32, 2127.

31. M. Nehru, S. Sumathi, International Journal of Applied Engineering Research, 2013, 8, 2179. 
A. AVRAM, T. FRENTIU, O. HOROVITZ, A. MOCANU, F. GOGA, M. TOMOAIA-COTISEL

32. K. Chojnacka, I. Michalak, Global Nest Journal, 2009, 11, 205.

33. A. Corami, S. Mignardi, V. Ferrini, Journal of Colloid and Interface Science, 2008, 317, 402.

34. R. Bazargan-Lari, M.E. Bahrololoom, A. Nemati, International Journal of Chemical, Molecular, Nuclear, Materials and Metallurgical Engineering, 2012, 6, 105.

35. T. Faezeh, M. Omid, H. Ebrahimzadeh, Indian Journal of Science and Technology, 2015, 8, 1.

36. Z. Abbasi, M. Aghababaei, Universal Journal of Engineering Science, 2014, 2, 124.

37. N. Gupta, A.K. Kushwaha, M.C. Chattopadhyaya, Advanced Materials Letters, 2011, 2, 309

38. E. Kusrini, N. Sofyan, D.M. Nurjaya, S. Santoso, D. Tristantini, Advanced Materials Research, 2013, 789, 176.

39. F. Fernane, S. Boudia, H. Saouli, Matec Web of Conferences, 2013, 5, 1.

40. H. Sawa, A. Takenaka, M. Hasegawa, K. Aoki, Phosphorus Research Bulletin, 1998, 8, 55.

41. A. Mocanu, R Balint, C. Garbo, L. Timis, I. Petean, O. Horovitz, M. TomoaiaCotisel, Studia UBB Chemia, 2017, 62, 95.

42. C. Garbo, M. Sindilaru, A. Carlea,.G. Tomoaia, V. Almasan, I. Petean, A. Mocanu, O. Horovitz, M. Tomoaia-Cotisel, Particulate Science and Technology, 2017, $35,29$.

43. Gh. Tomoaia, A. Mocanu, I. Vida-Simiti, N. Jumate, L.D. Bobos, O. Soritau, M. Tomoaia-Cotisel, Materials Science and Engineering C, 2014, 37, 37.

44. G. Tomoaia, O. Soritau, M. Tomoaia-Cotisel, L.-B. Pop, A. Pop, A. Mocanu, O. Horovitz, L.-D. Bobos, Powder Technology, 2013, 238, 99.

45. D Loca, M. Sokolova, J. Locs, A. Smirnova, Z. Irbe, Materials Science and Engineering C, 2015, 49, 106.

46. S. Lagergren, Kungliga Svenska Vetenskapsakademiens Handlingar, 1898, $24,1$.

47. Y.S. Ho, G. McKay, Process Biochemistry, 1999, 34, 451.

48. W.J. Weber, J. C.Morris, Journal of the Sanitary Engineering Division—American Society of Civil Engineers, 1963, 89, 31.

49. Gh. Tomoaia, O. Horovitz, A. Mocanu, A. Nita, A. Avram, C.P. Racz, O. Soritau, M. Cenariu, M. Tomoaia-Cotisel, Colloids and Surfaces B: Biointerfaces, 2015, 135,726

50. R.D. Pasca, G. Tomoaia, A. Mocanu, I. Petean, G.A. Paltinean, O. Soritau, M. Tomoaia-Cotisel, Studia Univ. Babes-Bolyai, Chemia, 2015, 60(3), 257.

51. G. Tomoaia, A. Mocanu, L.D. Bobos, L.B. Pop, O. Horovitz, M. Tomoaia-Cotisel, Studia Univ. Babes-Bolyai, Chemia, 2015, 60 (3), 265.

52. O. Horovitz, Gh. Tomoaia, A. Mocanu, T. Yupsanis, M. Tomoaia-Cotisel, Gold Bulletin, 2007, 40 (4), 295.

53. M. Tomoaia-Cotisel, A. Tomoaia-Cotisel, T. Yupsanis, Gh. Tomoaia, I. Balea, A. Mocanu, Cs. Racz, Revue Roumaine de Chimie, 2006, 51 (12),1181. 